\title{
Shrimp waste meal supplementation of cassava products based diet fed to broiler chickens
}

\author{
J. A. Agunbiade, B. O. Tolorunji and H. A. Awojobi
}

Department of Animal Production, Faculty of Agricultural Production and Renewable Resources, College of Agricultural Sciences, Olabisi Onabanjo University, P. M. B. 2002, Ago-Iwove, Ogun State, Nigeria.

\begin{abstract}
With the objective of investigating shrimp waste (SWM) and cassava leaf (CLM) meals as cheap alternatives and protein source mixtures that would best complement cassan'a root-sovbean ration in total replacement for maize in broiler diets, six iso-energetic and iso-nitrogenous diets were evaluated using two weeks old Anak broilers in a growth and digestibility trial lasting seven weeks. Diet 1 was a maize-soybean based control diet while diets 2 to 6 contained whole cassava root meal (WCRM) in total replacement for maize, energy for energy. Diet 2 had soybean meal (SBM) as a major source of protein taking the protein supplied by SBM in diet 2 as 100\%, SBM, CLM and SWM were combined thus in diets 3(0.5SBM: 0.5SWM), 4 (0.5SBM: 0.25SWM: 0.25CLM), 5(0.25 SBM: 0.5SWM: $0.25 \mathrm{CLM})$ and 6(0.5 SWM: $0.5 \mathrm{CLM}$. Average daily feed intake, weight gain $(P<0.01)$ and efficiency of feed conversion $(P<0.05)$ were significantly influenced by dietary treatments. Results indicate that replacing up to $50 \%$ supplemental protein of soybean meal with equal proportion of supplemental protein from SWM and CLM had no deleterious effects on rate and efficiency of weight gain in broiler chickens. While nutrient and energy digestibility and carcass characteristics except dressing percentage were unaffected by dietary treatment, there was indication that organs such as gizzard and small intestine were significantly tasked for digestive function, evident from the considerable increase in their weights in birds fed diets in which over $50 \%$ of soybean protein was replaced by $S W M$ and $C L M$. Based on the observation from this study, it can be concluded that not more than $50 \%$ of the dietary protein contributed by soybean should be replaced by SWM and CLM as doing otherwise would bring about a worsening effect on the performance of broilers.
\end{abstract}

Key Words: Cassava products based diets, shrimp waste meal, supplementation, broilers.

\section{Introduction}

Scarcity and high cost of common feed ingredients, particularly cereals and animal protein feed resources for example maize and fish meal has led to a renewed interest in the use of unconventional cheap and easily available ingredients of animal and crop residues in livestock feeding. For the latter category cassava products, viz: cassava root meal. cassava peel meal and cassava leaf meal have engaged the attention of researchers in recent time. For example in a growth trial with growing rabbits. Agunbiade et. al. $(1999,2000)$ observed that $100 \%$ replacement of maize by cassava leaf or 


\section{Agunbiade, Tolorunji and Awojobi}

cassava peel ' meal fortified with palm oil sludge or palm oil had no adverse effects on growth, performance and carcass characteristics. In addition, it has been reported that up to $50 \%$ of the protein supplied by soybean meal fed in conjunction with cassava peel meal can be replaced by palm kernel cake without adverse effects on rabbit performance (Agunbiade t. al., 2001).

A recent study on broiler chickens revealed relatively better performance of birds fed on cassava-soybean diets compared with maizebased control with further improvement in the performance of broiler chicken when soybeancassava rations were fortified with fish meal thus necessitating the use of animal protein source in such a feeding strategy (Agunbiade $e t$. al., 2002).

A suitable alternative animal protein source with potential for partial or total replacement of fish meal in livestock diet is shrimp (Rosenfeld et. al., 1997). With a pleasant aroma, palatability and crude protein content of $47.2 \%$, shrimp waste meal has been reported to be capable of replacing $66 \%$ of the protein supplied in broiler and weaned pig diets without any adverse effects on performance (Fanimo et. al., 1996).

This study was conducted to investigate shrimp waste meal as cheap alternative animal protein source and its appropriate combination with cassava leaf meal that would best complement whole cassava root meal in conjunction with soybean in total replacement for maize in broiler diets.

\section{Materials and Methods}

Source and preparation of cassava products and shrimp waste meal

The cassava product evaluated comprised whole cassava root meal WCRM) and cassava leaf meal CLM) obtained from $T \times 30055$ cassava variety sourced from I. I. T. A, lbadan and grown on the Teaching and Research Farm of the Olabisi Onabanjo University, Ago - Iwoye. The products were then harvested when the cassava crop was 16 months old. The umpeeled roots were sliced into thin chips, sun dried until practical dryness was achieved in about six days and milled to obtain WCRM. Fresh cassava leaves harvested without petioles were chopped into small sizes immediately after harvest, wilted under shade for 24 hours and sun-dried until practical dryness was achieved in about 6 days. The leaves were then crumbled to small particles to obtain CLM. The shrimp waste meal (SWM) in this study was a by-product of sea fish collected from Nigeria Institute of Oceangraphy and Marine Research (NIOMR), Lagos and was processed into dry meal through oven drying by CHI Aquatic Nig. Ltd., Lagos.
Preparation

Experimental Diets

Six dietary treatments (Table 1 ) formulated to be iso-energetic $(12.6-13.8 \mathrm{MJ} / \mathrm{kg})$ and isonitrogenous $192.2-200 \mathrm{~g} / \mathrm{kg}$ ) as much as possible and having energy to protein ratio maintained at about 0.68 were evaluated with Anak strains of broiler chickens for seven weeks (between the ages of two and nine weeks). The diets comprised two control diets (maize-soybean control and cassava root meal-soybean control) and the other four treatments which were made up of cassava-soybean basal with either shrimp waste meal or cassava leaf meal supplementing the protein supplied by the soybean meal (Table 2). 


\section{-Shrimp waste meal supplementation of cassava based diets for broilers}

Table 1: Composition of experimental diets (\%)

\section{Dietary Treatments}

\begin{tabular}{lllllll} 
Ingredients & \multicolumn{1}{c}{1} & 2 & 3 & 4 & 5 & 6 \\
\hline Maize & 60.93 & - & - & - & - & - \\
Whole cassava root meal & - & 52.64 & 49.74 & 40.84 & 37.89 & 27.4 \\
Soybean meal & 32.53 & 40.82 & 20.41 & 20.41 & 10.21 & - \\
Cassava leaf meal & - & - & - & 16.40 & 16.40 & 32.50 \\
Shrimp waste meal & - & - & 23.31 & 11.66 & 23.31 & 23.31 \\
Vegetable Oil & 2.14 & 2.14 & 2.14 & 6.29 & 7.79 & 12.00 \\
Fixed ingredients & 4.40 & 4.40 & 4.40 & 4.40 & 4.40 & 4.40 \\
Nutrient content & & & & & & \\
Crude protein \% & 20.00 & 20.00 & 20.00 & 19.64 & 19.54 & 19.22 \\
ME (MJ/Kg) & 12.56 & 13.84 & 13.20 & 13.19 & 13.16 & 12.88 \\
\hline \hline
\end{tabular}

Fixed ingredients consists of: bone meal (2.0), oystershell (1.0), salt (0.5), Vitamin / Mineral premix (0.5), methionine (0.2), Lysine (0.2).

Table 2: Dietary treatment showing component parts and proportion of crude protein supplied by them

\begin{tabular}{lll} 
Dietary Treatment & Component & Level of SWM, SBM, CLM,\% Inclusion \\
\hline 1 & Maize based control diet & $100 \%$ CP SBM \\
2 & Cassava based control diet & $100 \%$ CP SBM \\
3. & Cassava basal + SBM + SWM & CP 50\% SBM: 50 SWM \\
4 & Cassava basal + SBM + SWM + CLM & CP 50\% SBM: 25\% SWM: 25\% CLM \\
5. & Cassava basal + SBM + SWM + CLM & CP 25\% SBM: 50\% SWM: 25\% CLM \\
6 & Cassava basal + SWM + CLM & CP 50\% SWM: 50\% CLM \\
\hline
\end{tabular}

Soybean meal, (SBM); Shrimp waste meal (SWM) Cassava leaf meal (CLM).

A completely randomised designed was employed in which the birds were randomly allocated to three replicate groups of five birds each per treatment. Body weight changes, feed and water intake and mortality were measured weekly for each treatment group. At 8 weeks of age a digestibility trial was conducted during which excreta was collected quantitatively over the last seven days of the experiment. Experimental diets, ingredients and oven dried excreta from each replicate were analysed for gross energy (GE, ballistic bomb calorimetry) and proximate components according to $\mathrm{A}$. $\mathrm{O}$. A. C.(1995). Apparent metabolizable energy (AME) of the experimental diets was calculated by difference between the GE of the feed consumed and the GE of the excreta voided (Hill and Anderson, 1958). Similarly, determination of dry matter (DM), nitrogen and energy contents of diets and excreta allowed calculation of apparent dry matter (ADM), nitrogen (AND) and energy (AED) digestibilities.

At the end of the experiment, three birds from each treatment were randomily selected, fasted overnights, weighed the following morning and slaughtered by severing the carotid artery and jugulars vein. The carcasses were eviscerated and dissected and data collected included 


\section{Agunbiade, Tolorunji and Awojobi}

dressing percentage, weights of thigh, breast, drumstick, back and wing. Weights of the entire gastro intestinal tract (G.I.T), gizzard and small intestine with and without their contents along with the length of small intestine and some organ weights were also recorded. Data collected from the experiment were subjected to analysis of variance using a completely randomzed design as described by steel and Torrie (1980) Duncans New Multiple range Test (Duncan 1955) was employed in comparing differences among treatment means.

\section{Results and Discussion}

Table 3 shows the mean values for daily weight gain and efficiency of feed conversion of birds on the various experimental diets. There were highly significant, effects of dietary treatment on daily feed intake $(P<0.01)$, daily weight gain $(P<0.01)$ and efficiency of feed conversion $(P<$ 0.05 ) of birds fed the experimental diets. Birds fed diet 2, the cassava- soybean control at significantly more ( 83.0 vs $72.5 \mathrm{~g}$ ) and had significantly higher daily weight gain ( 30.2 vs 25.9) than those receiving the maize - soypean control diet $(P<0,01)$. No significant differences were observed in feed intake and daily weight gain of the birds fed diets 3 and 4 compared with those fed the maize-based control diet (i.e diet in which part of the soybean protein was replaced by either shrimp waste and cassava leaf meal proteins). Birds on diet 6 fed cassava basal plus supplemental protein from SWM and CLM without soybean ate the least and gained the least body weight with attendant poorest efficiency of feed conversion. The data in Table 3 indicate that replacing $50 \%$ supplemental protein of soybean meal when fed in conjunction with WCRM with equal proportion of supplemental protein from SWM and CLM (Diet 4) had no deleterions effect on the efficiency of feed conversion of broiler chickens. Considerably poor feed conversion efficiency, however resulted when more than $50 \%$ of soybean protein was replaced by the mixture of SWM and CLM protein (Diet 5).

Table 3: Effects of dietary treatment on performance characteristics of experimental birds

\begin{tabular}{|c|c|c|c|c|c|c|c|}
\hline \multicolumn{8}{|c|}{ Dietary Treatments } \\
\hline Measurements & 1 & 2 & 3 & 4 & 5 & 6 & SEM \\
\hline $\begin{array}{l}\text { Average daily weight gain } \\
\text { (g/bird) }\end{array}$ & $25.9^{\mathrm{cd}}$ & $30.2^{\mathrm{d}}$ & $21.7^{\mathrm{C}}$ & $22.8^{\mathrm{c}}$ & $16.3^{6}$ & $11.8^{\circ}$ & $2.47^{* *}$ \\
\hline $\begin{array}{l}\text { Average daily feed intake } \\
\text { (g/bird) }\end{array}$ & $72.5^{\mathrm{b}}$ & $83.0^{\mathrm{c}}$ & $61.7^{\mathrm{ab}}$ & $67.6^{\mathrm{ab}}$ & $63.4^{\mathrm{ab}}$ & $55.3^{\mathrm{a}}$ & $5.6 * *$ \\
\hline Feed conversion efficiency & $0.36^{\mathrm{c}}$ & $0.37^{\mathrm{bc}}$ & $0.35^{b c}$ & $0.34^{\mathrm{b}}$ & $0.26^{\mathrm{a}}$ & $0.22^{\mathrm{a}}$ & $0.04^{*}$ \\
\hline
\end{tabular}

* Means within the same row bearing different superscripts are significantly different

$*(\mathrm{P}<0.05) * *(\mathrm{P}<0.01)$

The mean dry matter, nitrogen and energy digestibility figures presented in Table 4 shows that differences in values due to dietary treatment were not statistically significant $(\mathrm{P}>$ $0.05)$. Generally energy and nutrients in the maize and cassava - based control diets and diet 3 were numerically more digestible than those of the remaining diets. The data showing characteristics of finished birds is shown in Table 5. With the exception of dressing percentage, the effects of dietary treatment on carcass characteristics were not statistically significant $(\mathrm{P}>0.05)$. The data showing dietary treatment effects on organ weight and gut dimensions presented in Table 6 indicate significant effects only on the weight of full gizzard $(\mathrm{P}<0.05)$, full $\mathrm{P}<0.01)$ and empty $(\mathrm{P}<$ $0.05)$ small intestine, cloaca $(P<0.05)$ and heart $(P<0.05)$ as well as on the length of the small intestine $(\mathrm{P}<0.01)$. 
Table 4: Energy and nutrient digestibility of experimental diets

Dietary Treatments

\begin{tabular}{lccccccc} 
Measurements & 1 & 2 & 3 & 4 & 5 & 6 & SEM \\
\hline Dry matter & 80.6 & 86.2 & 85.1 & 77.3 & 79.6 & 78.7 & 13.6 \\
Nitrogen & 84.2 & 85.0 & 82.3 & 84.4 & 84.5 & 78.3 & 6.37 \\
Energy & 90.7 & 87.1 & 86.8 & 80.9 & 81.8 & 81.3 & 4.94 \\
\hline \hline
\end{tabular}

SEM: Standard error of means

Table 5: Effects of dietary treatment on carcass characteristics of finisher birds

\begin{tabular}{|c|c|c|c|c|c|c|c|}
\hline \multirow[b]{2}{*}{ Measurements } & \multicolumn{4}{|c|}{ Diet Treatments } & \multirow[b]{2}{*}{5} & \multirow[b]{2}{*}{6} & \multirow[b]{2}{*}{ SEM } \\
\hline & 1 & 2 & 3 & 4 & & & \\
\hline Dressing \% & $70.95^{\mathrm{a}}$ & $66.76^{b}$ & $62.26^{\circ}$ & $67.23^{b}$ & $62.58^{\circ}$ & $61.78 \mathrm{c}$ & $1.90^{* *}$ \\
\hline $\begin{array}{l}\text { Wt of thigh (\% of dressed } \\
w t)\end{array}$ & 18.53 & 21.05 & 18.85 & 18.04 & 17.55 & 17.48 & 1.32 \\
\hline Wt of breast (\% of dress wt) & 25.08 & 23.71 & 25.18 & 23.14 & 19.46 & 22.63 & 2.26 \\
\hline $\begin{array}{l}\text { Wt of drum stick (\% of } \\
\text { dressed wt) }\end{array}$ & 10.84 & 11.91 & 11.53 & 11.36 & 10.82 & 12.55 & 1.64 \\
\hline $\begin{array}{l}\text { Wt of back (\% of dressed } \\
\text { wt) }\end{array}$ & 18.8 & 16.6 & 14.41 & 15.5 & 16.7 & 15.0 & 2.02 \\
\hline $\begin{array}{l}\text { Wt of shank (\% of dressed } \\
\text { wt) }\end{array}$ & 6.72 & 7.83 & 7.97 & 6.17 & 7.88 & 7.73 & 0.63 \\
\hline $\begin{array}{l}\text { Wt of wing }(\% \text { of dressed } \\
w t)\end{array}$ & 10.74 & 11.17 & 11.03 & 10.65 & 11.05 & 11.02 & 0.56 \\
\hline
\end{tabular}

Means within the same now bearing different superscripts are significantly different $(* \mathrm{P}<0.05)$;

$* * \mathrm{P}<0.01$ )

Table 6: Effects of dietary treatment on organ weight and gut dimension as \% body weight

\begin{tabular}{|c|c|c|c|c|c|c|c|}
\hline \multirow[b]{2}{*}{ Measizrements } & \multicolumn{5}{|c|}{ Dietary Treatments } & \multirow[b]{2}{*}{6} & \multirow[b]{2}{*}{ SEM } \\
\hline & 1 & 2 & 3 & 4 & 5 & & \\
\hline Full gizzard weight & $3.35^{8}$ & $3.78^{\text {ab }}$ & $3.97^{\mathrm{at}}$ & $3.91^{\mathrm{ab}}$ & $4.48^{b e-}$ & $5.61^{\circ}$ & $0.54^{*}$ \\
\hline Full small intestine & $4.63^{b}$ & $3.87^{\mathrm{a}}$ & $7.07^{\circ}$ & $4.64^{b}$ & $5.92^{\mathrm{bc}}$ & $7.36^{\circ}$ & $0.79^{* *}$ \\
\hline Empty small intestine & $2.85^{\mathrm{a}}$ & $2.96^{\mathrm{a}}$ & $3.90^{\mathrm{ab}}$ & $3.39^{\mathrm{a}}$ & $4.45^{a b}$ & $5.52^{b}$ & $0.79 *$ \\
\hline Heart & $0.60^{\mathrm{a}}$ & $0.90^{\text {cd }}$ & $0.82^{\text {cd }}$ & $0.76^{\mathrm{bc}}$ & $0.91^{d}$ & $0.62^{b}$ & $0.07 * *$ \\
\hline Cloaca & $1.34^{\mathrm{c}}$ & $1.15^{b c}$ & $1.05^{\mathrm{ac}}$ & $0.76^{\mathrm{ab}}$ & $0.77^{\mathrm{ab}}$ & $0.71^{\mathrm{a}}$ & $0.17^{*}$ \\
\hline Length of small intestine & $10.9^{b}$ & $9.24^{\mathrm{a}}$ & $15.5 b^{b c}$ & $15.0^{\text {bc }}$ & $19.3^{c}$ & $24.03^{\circ}$ & $2.04 * *$ \\
\hline
\end{tabular}

SEM: Standard error of means

Means within the same row bearing different superscript are significantly different $\left({ }^{*} \mathrm{P}<0.050\right.$;

$* * \mathrm{P}<0.01$ )

The superior performance of birds on cassavabased control over the maize-based control diet in this study whilst being at variance with the observation of Miller and Chou (1974) agrees 


\section{Agunbiade, Tolorunji and Awojobi}

with report of Gomez and Valdieso (1981) that cassava is superior to other sources of carbohydrate. Similar observation have been reported for broilers (Agunbiade et. al., 2002) and layers (Eruvbetine, 1995). Addition of palm oil to all WCRM-based diets apart from ensuring no deficiencies in essential long chain fatty acids could also have resulted in reduced dustiness, hence the observed improved palatability and feed intake as has been reported also by Summers and Leeson (1985). Another remarkable observation in this study is the fact that when fed in conjunction with whole cassava root meal, $50 \%$ of the protein supplied by soybean meal could be replaced with protcins from shrimp waste and cassava leaf meals without deleterious effects on the efficiency of the conversion of broiler feed to meat. The gradual decline in performance of birds observed beyond this level (diets 5 and 6 ) due to increasing level of both SWM and CLM agrees with the findings of Fanimo et al.. (1996) that increased level of inclusion of SWM leads to an increase in the level of dietary contained in the diet resulting in impairment of nutricnt digestion and absorption in the gastro intestinal tract of broilers. Although not significantly, this trend was almost becoming obvious from the digestibility results obtained in this trial (Diets 4,5 , and 6 . Table 4 ). The observation above is further corroborated by the observed general increase in the relative weights (full gizzard, full and empty small intestine) and length (small intestine) of organs as the proportion of both SWM and CLM increased particularly in diets 5 and 6 . This findings is in consonance with the report of Fanimo et. al. (1996) who reported increased relative weight of gizzard. small intestine, heart and cloaca and length of small intestine of broilers fed increasing levels of SWM.

\section{Conclusion}

Based on the results of this trial it can be concluded that cheap feeds for broiler feeding could be formulated by replacing sovbean with cheap alternative protein sources such as shrimp waste and cassava leaf meal. However, not more than $50 \%$ of dietary protein contributed by soybean should be replaced as doing otherwise would bring about a worsening effect on the performance of broilers.

\section{References}

Agunbiade J. A., Adeyemi O. A, Fasina O. E, Ashorobi B. O, Adebanjo M. O. and Waide 0. A. 1999. Cassava peels and leaves in the diet of rabbits: Effect on performance and carcass characteristics. Nig. J. Anim. Prod. 26: 29-34

Agunbiade, J. A., Adeyemi O. A., Adepoju O. A. and Lawal O. A. 2002. The use of whole cassava meal and leaf meal in broiler diets. Trop J. Anim. Sci. 5(1) 161 173.

Agunbiade, J. A., Adeyemi O. A., Fasina 0. E. and Bagbe S. A. 2001. Fortification of cassava peel meal in a balanced diet for rabbits. Nig. J. Anim. Prod. 28(2) 167-173.

Agunbiade, J. A. Bello R. A., Adeyemi O. A. 2002. Performance characteristics of weaner rabbits on cassava peel - based balanced diets. Nig. J. Anim. Prod. 29 (2) $171-175$

A. O. A. C. 1995 . Official methods of analysis $\left(18^{\text {th }} \mathrm{Ed}\right.$.) Association of Official analytical chemist Washington D. C.

Duncan, D. B. 1955. Multiple range and Multiple F. Test. Biom. 14: 1-12

Eruvbetine, D. 1995. Processing and utilization of cassava as animal fecd for non-ruminant Animals. Paper presented at the Lagos Statc ministry of Agriculture Report.

Fanimo, A. O, Mudama E, Umukoro F. 0 . and Oduguwa O. O. 1996. Substitution of shrimp wastc meal for fish-meal in broiler chicken rations. Trop. Agric. (Tinidad) 73 (2); 201-205 


\section{Shrimp waste meal supplementation of cassava based diets for broilers}

Gomez, G. and Valdieso, M. 1983. The effect of variety and plant age on cyanide content. Chemical composition and quality of cassava root. Nutr. Rep. Int; (4) 857 865.
Hill, F. W. and Anderson D. I. 1988 Comparison of metabolizable energy and productive energy determinations with growing chicks. J. Nutr. $64 ; 587-603$.

(Received 27 July 2003; Accepted 30 November 2003) 